San Jose State University

SJSU ScholarWorks

Master's Theses

Master's Theses and Graduate Research

Spring 2017

\title{
Construction of Bacterial Strains Containing a Plasmid Producing an Opossum-Based Anti-Venom Peptide for Low Cost Production of the Peptide
}

Angela Cifelli

San Jose State University

Follow this and additional works at: https://scholarworks.sjsu.edu/etd_theses

\section{Recommended Citation}

Cifelli, Angela, "Construction of Bacterial Strains Containing a Plasmid Producing an Opossum-Based Anti-Venom Peptide for Low Cost Production of the Peptide" (2017). Master's Theses. 4792.

DOI: https://doi.org/10.31979/etd.3g8r-z8jw

https://scholarworks.sjsu.edu/etd_theses/4792

This Thesis is brought to you for free and open access by the Master's Theses and Graduate Research at SJSU ScholarWorks. It has been accepted for inclusion in Master's Theses by an authorized administrator of SJSU ScholarWorks. For more information, please contact scholarworks@sjsu.edu. 
CONSTRUCTION OF BACTERIAL STRAINS CONTAINING A PLASMID PRODUCING AN OPOSSUM -BASED ANTI-VENOM PEPTIDE FOR LOW COST PRODUCTION OF THE PEPTIDE

\author{
A Thesis \\ Presented to \\ The Faculty of the Department of Biological Sciences \\ San José State University \\ In Partial Fulfillment \\ of the Requirements for the Degree \\ Master of Science
}

By

Angela Cifelli

May 2017 
(C) 2017

Angela Cifelli 
ALL RIGHTS RESERVED

The Designated Thesis Committee Approves the Thesis Titled

CONSTRUCTION OF BACTERIAL STRAINS CONTAINING AN OPOSSUMBASED ANTI-VENOM PEPTIDE FOR LOW COST PRODUCTION

by

Angela Cifelli

\section{APPROVED FOR THE DEPARTMENT OF BIOLOGICAL SCIENCES SAN JOSÉ STATE UNIVERSITY}

May 2017

Sabine Rech, PhD. Department of Biological Sciences

Claire Komives, $\mathrm{PhD}$. Department of Engineering

Leslee Parr, PhD. Department of Biological Sciences 


\begin{abstract}
by Angela Cifelli

A cost-effective therapy for snake bites and other biological toxins could save thousands of lives each year. A low-cost therapy can be achieved using a bacterial host that expresses a peptide that prevents death when administered after exposure to these toxins. A protein expressed in opossums, lethal toxin neutralizing factor (LTNF), provides the animal's resistance to venom and a variety of other toxins. A small peptide fragment of this protein provides the same lifesaving properties as the full protein sequence. A synthetic copy of this peptide was tested in mice exposed to rattlesnake venom and showed lifesaving potential. The peptide was expressed in E. coli and the feasibility of a lower cost process for producing an anti-venom therapy was shown. Two E. coli strains were constructed: snk1 and snk23. This was accomplished by introducing expression vectors containing the peptide sequence alone or a polypeptide sequence that contains 23 repeats of peptide. Once the bacterial cells were transformed with the antivenom DNA, the peptide was produced in shake flasks and scaled up to $2 \mathrm{~L}$ fermentations. While confirming the expression of the single peptide is ongoing, the larger polypeptide was expressed and recovered in inclusion bodies.
\end{abstract}




\section{TABLE OF CONTENTS}

List of Tables.............................................................. vi

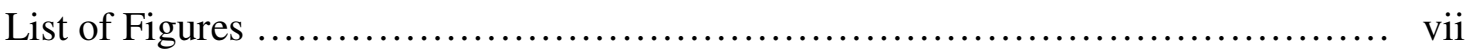

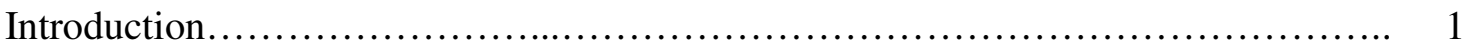

Literature Review...................................................................... 4

Industrial Scale Peptide Production..................................... 4

Molecular Basis of Adapting Bio-Based Systems for Peptide Production..... 5

Current Peptide Therapies............................................ 10

Methods for Industrial Scale Production of Peptides..................... 15

Limitations and Potential.................................................. 17

Material and Methods........................................................... 22

Plasmid Prep.............................................................. 22

Cloning and Sub-Cloning ................................................. 24

Expression and Recovery of Peptide.................................. 25

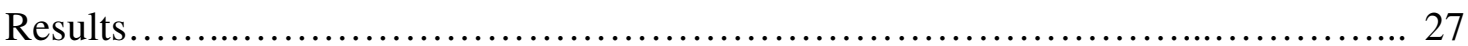

Plasmid Construction................................................ 27

Expression and Downstream Recovery.................................. 28

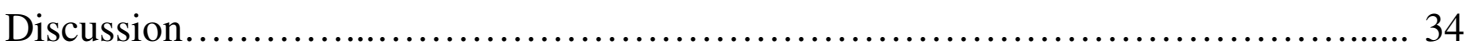

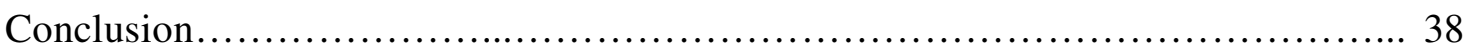

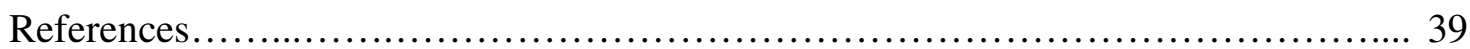




\section{LIST OF TABLES}

Table 1. Classification of some antimicrobial peptides............................ 14

Table 2. Summary of survival results in mice exposed to toxins.................... 21 


\section{LIST OF FIGURES}

Figure 1: Cloning LTNF synthetic genes onto expression vector with novablue cells and euorfin plasmid............................................................... 23

Figure 2: $\quad$ Insert optimized for expression of LTNF10 peptide........................... 24

Figure 3: $\quad$ DNA gel verifying the presence of snk1 ......................... 27

Figure 4: $\quad$ SDS PAGE gel showing protein expression in the cell lysate.......... 29

Figure 5: SDS PAGE gel showing snk25 expression time course during shake flask experiment..................................................... 30

Figure 6: $\quad$ SDS PAGE gel from snk25 fermentation samples................ 31

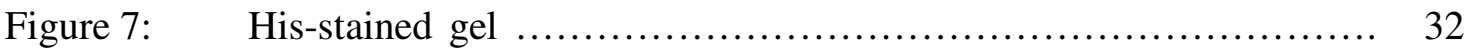

Figure 8: $\quad$ His-stained gel from fermentation of $\operatorname{snk} 25 \ldots \ldots \ldots \ldots \ldots \ldots \ldots \ldots \ldots \ldots$ 


\section{Introduction}

Small peptides with innate bio-functionality are one of nature's mechanisms for fighting and preventing diseases originating from microbial infections, viral infections and toxins including biological toxins such as venom (Hartmann, 2007; Kitts, 2003; Yoshikawa, 200). They are present in all life forms and play an important role in the innate immune response for plants, animals, prokaryotes and eukaryotes. Peptides consist of amino acid sequences and are often generated through the hydrolysis of a parent protein (Meisel, 1990). Exploiting these activities for use as naturally occurring therapeutic agents could lead to a lower cost alternative compared with synthetic based therapies. Development of an anti-venom peptide has significant potential to save human lives. Envenoming snake bites affect 5 million people every year and cause nearly 100,000 deaths, with an additional 400,000 people experiencing other serious consequences, including amputations and infections (Arnold, 2016; Kasturiratne, 2008). Venom consists of complex proteins and can be neurotoxic, hemotoxic or both. Several rodents and other small animals have anti-hemorrhage activity, preventing the effects of many biological toxins. The opossum, Didelphimorphia, is a large order of marsupials found in the western hemisphere that has a specialized immune system. This immune system allows it to be resistant to most types of venom and have the ability to tolerate a diet containing rotting fruits and other human garbage. Didelphimorphia produces lethal toxin neutralizing factor, LTNF, a metalloproteinase inhibitor which protects against environmental toxins such as venom (Krause, 2006; Lipps, 1999; Oerez, 1979). Evolution of this ability to inhibit the toxins may have coevolved with the toxins. The 
possum species that are resistant to toxins are also predators of venomous snakes (Jansa, 2011).

The anti-venom protein was isolated from opossum serum and showed potential as use for anti-venom therapy by preventing death in mice that had otherwise perished (Lipps, 1999). It was later shown that this protein could be fractionated into small peptide fragments that have the same efficacy as the full LTNF protein (Lipps, 2000). Next, the Lipps lab showed that the smaller peptide fraction can reverse the effects of the biotoxins such as snake venom. The peptide fragment chosen for this study was a 10-amino acid sequence that was identified after showing strong affinity to anti-LTNF in a binding assay. This was shown after the N-terminus fragment was sequenced: Leu-Lys-Ala-MetAsp-Pro-Thr-Pro-Pro-Leu and later synthesized. The peptide, LTNF-10, then showed similar efficacy to its parent LTNF protein when mice were exposed to a variety of biological toxins including snake venoms (Lipps, 2000).

After inserting the gene (cassette) coding for this peptide into a microbial host, the microbe can express the peptide. E. coli was the organism chosen to express this peptide. A tryptophan was added to the end of the 10-amino acid sequence. This was naturally the 11th amino acid in the sequence of the protein and may offer alternate strategies for processing the poly-peptide as this is a site for hydrolysis by enzymes like chymotrypsin. Polyhistidine-tagging (His-tag) the peptide onto a plasmid in an E. coli based protein expression system has been shown to improve overall yields and purity while maintaining peptide efficacy (Catanzariti, 2016; Zhao, 2011). The his-tag, usually containing 6 histidines, can be located on the $\mathrm{N}$ or C-terminus of the protein. Purification will be 
facilitated when a protein is His-tagged because it will bind to metal ions and kits are available with nickel or cobalt resins. Quantification and purity can then be determined using ELISA, western blots or SDS-PAGE. For this research, the peptides were Histagged for more straightforward purification, visualization and validation. This $6 \mathrm{x}$ his tag is found at the $\mathrm{N}$-terminus of the peptide sequence.

The production of therapeutic peptides is a successful market. Peptide production is currently being used for production of antibiotics as an alternative to small molecules like penicillium which has led to antibiotic resistance for many types of human infections. Organisms used as expression vectors should grow fast, produce a lot of the desired proteins and have fewer nutritional requirements for growth conditions. Usually, strains are altered to facilitate the highest production of the desired peptide. E. coli and $P$. pastoris are common organisms.

This research summarizes the expression of the peptide identified by the Lipps lab as LTNF-10 as a potential therapeutic treatment for snake bites. With the addition of the tryptophan, our peptide contains 11 amino acids. The synthesized version of this 11amino acid peptide was shown to provide lifesaving properties in mice exposed to rattlesnake venom. While this dosing strategy will require optimization, it is a very promising result and using biotechnology to express this peptide in a more economical process is not expected to alter its efficacy. 


\section{Literature Review}

\section{Industrial Scale Bio-Based Peptide Production}

Synthetic production of peptides is available but can often be cost prohibitive. Microbes are excellent tools for industrial-scale peptide production because their life spans are short so many generations can be studied in a relatively short amount of time and they are relatively inexpensive to grow. Bacteria are extremely adaptable and their ability to adjust quickly to new environments has led them to develop selective advantages. The rapid growth and reproduction rates of bacteria has put their evolution on a different scale compared animals and allow billions of cells to be evaluated economically and in a reasonable time frame. Advances in biotechnology and genome sequencing have enabled humans to take advantage of this adaptability. In biofuel production, enzymes are required to produce the glucose that feed the yeast that make the ethanol. The microbes that produce these enzymes have been genetically engineered to be faster, more robust and be able to produce at minimal cost. These advancements have led to developing lower cost consumer products and also reduce the use of chemicals that can harm the environment and are expensive to synthesize. (Fogarty, 2012; Glenn, 1976).

Escherichia coli (E. coli) is a well understood organism, making this species a popular expression system for proteins and peptides. Pathways of protein production can be altered to meet an industrial need. For example, one protein may need to be overexpressed to produce more of a second protein (Miroux, 1996). Simply inserting genes in multiple copies to increase production can often be toxic to the $E$. coli cells and disrupt important feedback mechanisms that sustain fitness and communicate to the cell how to 
respond appropriately. It usually takes many manipulations of the cell to make an economically viable production host on an industrial scale (Sørensen, 2005). While peptides are chemically derived, it can still be more economical to generate these molecules in living organisms such as E. coli. Once an expression system has been identified, optimization of the whole system will be needed before these peptides reach their full potential as therapeutic agents. The optimized systems would include: improved peptide yield, solubility and efficacy under true physiological conditions including resistance to protease degradation.

\section{Molecular Basis of Adapting Bio-Based Systems for Peptide Production}

When making a bio-based system for peptide production, it is important to understand how the organism responds and adapts to new conditions. In the past, mutagenesis was used to change an organism's genome but even when one is deliberately changing the DNA through insertion of an exogenous gene, the cell's transcription process still needs to function properly. Knowing the mechanisms behind peptide expression can help with troubleshooting when expression is poor. A change in the DNA will change the mRNA sequence which can lead to a new protein sequence. The SOS response system after DNA damage was one of the first well characterized systems showing how $E$. coli alters its cellular mechanisms in response to stress. Cells that do not undergo stress do not induce the SOS response activity that involves expression of lexA and recA gene products and inhibition of DNA nucleases that degrade damaged DNA (Witkin, 1976). The response systems after UV damage are controlled by master regulators, for example, polymerases, and the same enzymes are involved in the responses to various other harsh conditions. $E$. 
coli encodes five DNA polymerases, three of which are induced through the SOS response to DNA damage. These polymerases are error prone, leading to genetic diversity and survival during stress conditions. Using isogenic mutations with all possible combinations of the three polymerases, the expression patterns and roles of the polymerases were studied during a different kind of stress condition, famine. The study revealed that any of the polymerases can randomly generate a mutation even in the absence of external stresses such as UV damage. During times of nutrient limitations, cells may go into the stationary phase and during this phase, DNA replication is susceptible to more errors. Each polymerase has specific roles and, likely, a competitive hierarchy for access to the DNA. During this famine-induced stress, Pol IV and V seem to be better at producing genetic variation including beneficial alleles than Pol II, based on studies of mutants expressing only one of each of these polymerases. However, Pol II also plays a role in genetic diversity during periods of rapid cell growth and improves replication efficiency during the stationary phase, allowing new alleles to arise following the low fidelity transcription of Pol IV and V (Corzett, 2013). Beneficial adaptations are the result of several activities, and bacteria adapt their transcription machinery under genomic mutations, in cases of UV damage, or environmental stresses, such as starvation.

Bacteria can change cellular components as needed to withstand harsh environmental conditions. Gram negative bacteria are susceptible to acidification of their periplasmic space because the outer membranes contain porins, channel-forming proteins that allow protons and other small molecules in. The proteins associated with the periplasmic space do not function properly under acidic conditions and can affect the cell's viability unless 
they can quickly adapt (White, 1995). When E. coli is exposed to an acidic environment, it will send signals to the transcription machinery. This communication changes the transcription mechanism to make chaperones that help proteins fold into their proper tertiary structure. The folding could be misguided in an acidic environment because proteins are normally produced at a neutral $\mathrm{pH}$. They may be insoluble or aggregate before proteins are folded into its proper tertiary structure. E. coli can survive an acidic environment when acid-activated chaperones help alleviate acid-induced damage caused by acidification of its intracellular environment. Periplasmic chaperones, HdeA and HdeB, undergo conformational changes in an acidic environment. Without expression of these proteins, cells cannot survive the acidic environment. HdeA is dimeric but will dissociate into its active monomeric forms when protonation of negatively charged amino acids causes the protein to partially unfold below $\mathrm{pH} 3$. At $\mathrm{pH}$ below 3, HdeB is not active in its monomeric form. Above $\mathrm{pH} 3$ and optimally at $\mathrm{pH} 4, \mathrm{HdeB}$ in its dimeric form is most active and promotes healthy growth in this acidic environment (Dahl, 2015). It has been shown that HdeA associates with other periplasmic chaperones to prevent their aggregation (Hong, 2012; Wang, 2012). Streptococcus mutans survives the acidic environments of the mouth. The mechanism behind this adaptation is increased production of monounsaturated fatty acids (UFAs) in membranes of bacterium. Cardiolipin plays a role in increasing UFA production, and deletion of this gene results in decreased production of UFAs and increased acid sensitivity (MacGilvray, 2012). Cardiolipin also protect bacteria under high osmotic environments. Staphylococcus aureus can grow in high salt environments. It was shown through lipid analysis that 
cardiolipin is required for the organism to sustain growth in high salt environments (Tsai, 2011). Cardiolipin is required for survival to more than one stress response. Heat-induced stress has also led to beneficial mutations.

Another example E. coli change its expression of surface proteins to be resistant to silver, genomes were sequenced after selecting colonies that had developed resistance to silver for six continuous days (Randall, 2015). To develop this resistance, it must be able to upregulate the transport of the silver out of the cell. To achieve this, they lose functional surface proteins, OmpC and OmpF porins, and gain function of the Cus efflux mechanism responsible for the export of silver. After sequencing genomes from resistant strains, it was found that there were mutations in genes the coded for surface proteins: OmpC and OmpF porins, regulators of porins and the Cus transporter (Randall, 2015). Several populations evolved at $42{ }^{\circ} \mathrm{C}$. The genomes were sequenced after 2000 generations, and more than 600 sites with mutations were identified. There was a pattern in that the heat tolerant mutations were at the gene and operon level, and not after protein expression (Tenaillon, 2012). Understanding the mechanisms to stress can be used to modify and improve fitness of cells under desired conditions.

Cells may even use their own building blocks to make a desired compound. Microbes are used to make bio-butanediol (BDO) using building blocks from their own central metabolism. By rearranging order of gene expression, an E. coli strain was identified that had enhanced the BDO pathway by enhancing the utilization of oxygen in the citric acid cycle (Yim, 2011). Pathway engineering used to make precursors to biofuels creates a very harsh environment for the cells by altering the cell's viscosity. It can be overcome 
by enhancing the secretion machinery of the cells. This requires the manipulation of transport proteins that carry the proteins outside the cell. These proteins are now identified with next generation sequencing, NGS and are further being studied for their ability to enhance protein production and cell viability. Protein pumps have been engineered to transport more efficiently, which ultimately leads to increased yields. Increasing production of more fit transport proteins led to increased production fatty acids which are esterified into biofuel (Lennen, 2011; Lennen 2013).

Identifying mutations that increase expression of a gene or provide fitness benefits often requires screening of billions of cells so being able to grow cells cheaply is ideal. Strains with beneficial mutations of naringenin and glucaric acid were identified after such screening. Naringenin is an antioxidant that is implicated in human health, and glucaric acid can be used as a more sustainable replacement for petroleum based polymers (Raman, 2014). An ideal expression system may depend on many factors and once scaling to industrial scale, cost will be a factor. E. coli can be fed a cheaper medium such as Luria Bertani (LB) broth. With more sophisticated molecular biology techniques and with the help of NGS, more genes are being implicated in response to different stresses, and more strains have been generated for a wide range of purposes, including production of biofuels and protein or peptides. This information has advanced our knowledge and understanding of which genes are involved when a new phenotype is observed or gene is overexpressed. With a more holistic understanding of the cell's molecular machinery, we can learn how to take advantage of a bacterium's ability to adapt to changes in environment and genome, eventually leading to the engineering of 
more efficient microbial strains for protein and peptide production. Peptide therapies currently being produced will be discussed in the next section.

\section{Current Peptide Therapies}

An example of a successful bio-based peptide therapy is Gramicidin, used as an antibiotic to treat sore throats and has activity against a wide range of microbes including bacterial and fungi. When producing Gramicidin, medium changes had an impact on the formation of Gramicidin synthase which is required for the synthesis of Gramicidin within a host cell. By limiting nutrients such as phosphate, nitrogen, carbon and sulfur, the production of the antimicrobial peptide was altered (Matteo, 1976). Cationic peptides are becoming more appealing for use as antibiotic resistance to small molecules such as penicillin and amoxicillin increases. Though these traditional antibiotics were important treatments for warding off bacterial infections in the past, rapid rates of evolution have led to a greater need to develop alternative antimicrobial strategies. The mechanism of kill using peptides can be direct, when there is disruption of the cell wall, or by signaling degranulation, resulting in toxins being secreted from the bacterial cells (Hartmen, 2007). The wide variety of cationic peptides that exists within a species (and from all life forms) means better specificity towards different cell types and the ability to co-evolve with microbes, decreasing chance of resistance (Peschal, 2006).

There are several classes of antimicrobial peptides and within humans, three families have been identified: defensins, cathelicidins and histadins (Rossi, 2008). Regardless of species, they are typically found in the mucus membranes of cells. Their ability to distinguish between the host and microbial cells indicates that their expression is highly 
regulated and the inherent structure makes them highly selective (Yeaman, 2003).

Antimicrobial resistance to cationic peptides is less frequent compared to small molecule antibiotics in vivo. In vitro experiments have shown that bacteria will develop resistance to these peptides over time. It could be that there is co-evolution occurring among the host-defense peptides and bacteria. Under true physiological conditions the peptides are evolving and cells are signaled to generate different peptide cocktails depending on the infection (Peschel, 2006). The diversity of the peptides within a host also indicates rapid evolution of these peptides as exposure to pathogens increases. It is still unknown how fast resistance to these peptides occur or if the peptides co-evolve at the same rate. Bacterial production of proteases or peptidases which degrade peptides, is constantly evolving. Despite the wide variety of sequences within each class of antimicrobial peptides, structure and activity relationships seem important. Fewer disulfide bridges will make peptides more susceptible to the proteolysis however more disulfide bridges make the molecule less flexibility.

Defensins are the most abundant antimicrobial peptide with activity against Gram + and Gram - bacteria in addition to fungi, yeast and viruses (Hancock, 1998; Hancock, 2002). Defensins are typically $\beta$-sheets containing disulfide bridges making them more resistant to protease degradation but will require more stringent conditions (i.e. low sodium chloride) upon entrance into an invasive cell. Gramicidin S, polymyxin B and MBI 594AN are topical treatments used as an antifungal or antibiotic to counter infections leading to acne. Gomesin from the spider Acanthoscurria gomesiana has been shown to reduce candidiasis, a yeast infection that now has resistance to the traditional 
antifungal treatments which include polyenes, azoles and echinocandins but has not been approved yet as a therapy (Rossi, 2012). LL-37 is an antibiotic that can act as an antimicrobial but will also act like a chemokine attracting leukocytes. LL-37 is a linear peptide that is highly susceptible to protease degradation and will have limited applications in vivo. Hepcidin is a cationic peptide that acts like an antimicrobial and a hormone than can regulate iron production. Iseganan is being developed as an aerosol for respiratory type infections caused by pneumonia, cystic fibrosis, or chemotherapy side effects (Bush, 2004).

Cationic peptides with antimicrobial properties have an overall charge from $+2-+11$ and regions of hydrophobic residues that give the folded peptide an amphiphilic motif (Hancock, 1998; Hancock, 2006). These peptides can form a variety of secondary structures ( $\beta$-sheets, $\alpha$-helices, loops) and differ widely in the size and sequence length. The overall positive net charge of the peptide interacts with the anionic cell surface and the amphiphilic properties allow it to insert itself into the cell's membrane. The peptide can act either by disrupting the integrity of the cell wall allowing toxins to enter or through migration into the cell subsequently acting on internal targets (Toke, 2005). In addition to the phospholipids present, membranes are composed of several proteins which are fundamentally different among all organisms. The membranes of eukaryotes will contain sterols that contain a net neutral charge that are normally not in prokaryotic cells. Prokaryotic cells may contain more negatively charged hydroxylated phospholipids. The host peptide is distinguishing the invasive species by determining membrane composition through its affinity for membrane electrochemistry (Hancock, 2002). The amount of 
negatively charged proteins and number of hydrophobic proteins on the cell membrane will guide the peptides selection for which cells to target. Peptide conformation will also influence interaction with target cells. The disulfide bonds influence the flexibility of the peptide. Among the human $\beta$-defensins, hBD1, hBD2 and hBD3, their overall charge increases. Compared with hBD1 and hBD2, hBD3's net +11 charge enables the formation of six distinct secondary structures, while hBD1 and hBD2 preferentially folds into one structure. Interestingly, the antimicrobial efficacy of the 6 forms of hBD3 is effective against $E$. coli but the chemotactic (interactions with chemical stimulus) activities will vary. Additionally, the antimicrobial activity is independent of salt concentration which plays an important role in membrane permeability. The decoupling of antimicrobial activity and chemotactic activity with $\mathrm{hBD} 3$ is indicative that a net +11 charge will overpower the structural enablement of the peptides permeability across the cell membranes (Wu, 2003).

Most antimicrobials kill cells through lysis but some cationic peptides have a different mechanism of antimicrobial activity. Parbutoporin isolated from scorpion venom can induce degranulation signaling the cells to secrete cytotoxins (Remijsen, 2010). In addition, they can work synergistically with each other by making heterodimers that will stabilize pores formed or when one peptide opens a channel for a second peptide to act on an internal target (Yeaman, 2003). These peptides are not immune to resistance and organisms can fight against these antimicrobials by: generating proteases that degrade the peptides, generating other protein that form a biofilm around the peptide and prevent it from entering the cell and through secretion of the peptide or by altering the 
charge on the cell's surface subsequently preventing the peptide from binding and/or entering the cell (Peschel, 2006). Although bacteria will likely not replace the anionic components of the cell wall, they can alter them such that the overall charge of the cell surface is reduced. For a more complete list, see the antimicrobial peptide database maintained by the University of Nebraska Medical Center. Some examples of therapeutic peptides out on the market can be found in Table 1.

Table 1. Classification of Some Antimicrobial Peptides

\begin{tabular}{l|ll}
\hline $\begin{array}{l}\text { Peptide } \\
\text { Class }\end{array}$ & General Description & Examples \\
\hline Defensins & $\begin{array}{l}\text { antimicrobial peptide of diverse } \\
\text { origin, usually adopting a } \beta \text {-sheet } \\
\text { structure with three intramolecular } \\
\text { disulfide bridges } \\
\text { linear antimicrobial peptide }\end{array}$ & $\begin{array}{l}\text { Plectasin-fungal anti gram positive } \\
\text { antibiotic } \\
\text { Crytdin- } \alpha \text {-defensin produced by mice }\end{array}$ \\
$\begin{array}{l}\text { Lantibiotic } \\
\text { Othelicidin }\end{array}$ & $\begin{array}{l}\text { LL-37- human antibiotic and only } \\
\text { antimicrobial peptide produced by positive bacteria which } \\
\text { gramtains lanthionine and/or } \\
\text { methyllanthionine amino acids } \\
\text { with thioester bridges }\end{array}$ & $\begin{array}{l}\text { Nisin-lactic acid-producing bacteria } \\
\text { (LAB) generated antibiotic }\end{array}$ \\
& & $\begin{array}{l}\text { Hepcidin-related CAMP- vertebrate } \\
\text { peptide with antimicrobial and iron } \\
\text { metabolism regulating hormone-like } \\
\text { activities }\end{array}$ \\
\hline
\end{tabular}

When developing a process for making therapeutic peptides, the conditions can be optimized to provide an environment where the peptides are properly folded and in an optimally stable and effective state. While feasibility has been demonstrated to develop these into effective antibiotics, it should be considered that only few of these products are 
currently on the market and mostly applied topically due to low viability in human serum (Bowdish, 2005).

\section{Methods for Industrial Scale Production of Peptides}

Discovery screening tools have enabled the unveiling of several new and novel peptides from a wide range of hosts including mammalian, plant and microbial cell lines. In addition, process screening tools are available for optimization of process parameters including: strain selection, growth conditions and most favorable sequence. An expression host should grow fast, produce a lot of proteins and have fewer nutritional requirements. Usually strains are altered to facilitate the highest production of the desired peptide. E. coli and P. pastoris are common organisms for antimicrobial peptide production. Following the identification of the optimum system for production of the peptide or pro-peptide, the next challenge is the yield, stabilization and maintaining efficacy.

Yields can be improved by adding enzymes specific for hydrolyzing the parent protein into smaller peptides. Thermolycins, proteases, alcalases and trypsins have all been shown to be involved in the production of peptides from larger molecules. If the parent protein is expressed and requires modification after secretion from the cell, additional enzymes can be induced or added to catalyze the hydrolysis and generation of the bioactive peptide. By co-expressing other proteins, it is possible to minimize aggregation and increase solubility and bio-availability. Over-expressing molecular chaperones have been shown to help minimize aggregation by assisting with proper 
folding (Mogk, 2003). The solubility behavior is an important property during purification of the peptide.

Polyhistidine-tagging (His-tag) the peptide by using a plasmid in an E. coli based protein expression system does improve overall yields and purity while maintaining antimicrobial efficacy (Catanzariti, 2004; Zhao, 2012). The his-tag usually contains 6 histidines placed on the $\mathrm{N}$ or $\mathrm{C}$-terminus of the protein. Kits are available with nickel or cobalt resins for purification. Quantification and purity can then be determined using Enzyme-linked immunosorbent assay (ELISA), western blots or sodium dodecyl sulfate polyacrylamide gel electrophoresis (SDS-PAGE).

While his-tagging proteins is useful for lab scale experiments, it may be too costly for larger scale processes. The most common purification methods at manufacturing scale are ultrafiltration and chromatography. They may be used in combination depending on the target industry and purity requirements. Membrane technology has been used to fractionate several peptide products from hydrolysates of fish waste (Chabeaud, 2009). Four bioactive peptides generated from hydrolysates of porcine collagen were purified using a multi-step process with gel filtration and ion exchange chromatography ( $\mathrm{Li}$, 2007). This type of process can be useful when purifying peptides from lysates. In the case of antimicrobial peptides, they may be working with other cellular components synergistically or adversely. This makes some purification techniques too selective or not selective enough. A few alternatives to ultrafiltration and chromatography have been developed including a one-step heat treatment that was used to isolate an antimicrobial peptide from Aspergillus clavatus. This particular fungal peptide is extremely heat stable. 
After the 15 -minute treatment at $100 \mathrm{C}$, the peptide was the only small protein left in the supernatant and the heat treatment had no effect on the activity against bacteria (Hajji, 2010). Other potential process changes might include alterations in $\mathrm{pH}$, conductivity and osmolality, to name a few.

After a process is developed for making the peptide(s), the next requirement is to package it for its application while maintaining its stability and efficacy. The challenge with proteins is they tend to be unstable in solutions. Drying and tableting the peptide will improve the shelf life but it is often necessary to provide a liquid formulation. Usually, stabilizers (polyols, sugars, salts) are added but for therapies, the list of acceptable stabilizers is quite small. Lung infections applications are using aerosols and mouthwash as a topical treatment and is currently the preferred application for iseganan which is used to treat lung infections from cystic fibrosis patients, pneumonia and those with respiratory infections due to side effects from chemotherapies (Bush, 2004). Topical treatments are often preferred due to low viability in human serum (Hancock, 2006).

\section{Limitations and Potential}

The challenge is almost always the economics of developing these into products. In the biofuels sector, moving towards bio-based fuels to be more sustainable has been successful and is becoming more cost effective. In this case, there was the added challenge of utilizing the right feedstock that does not impact the food supply or the cost of food. Maize was the first-generation feedstock and now lignocellulose can be utilized. The economics has mostly been achieved through pathway engineering metabolism to produce the hydrocarbons and by engineering cells to make the enzymes to better 
hydrolyze the cellulose based substrates (Bokinsky, 2011; Huffer, 2012). One approach to making the advanced biofuels more economical was to engineer $E$. coli to over express the necessary enzymes for substrate hydrolysis: xylanase, cellulase, beta-glucosidase. In addition, these strains could grow with cellulose and hemicellulose in the feedstock (Bokinsky, 2011).

Advancements in screening tools and industrial microbiology could mean bio-based production is more cost-effective than chemical peptide synthesis. Success with engineering these peptides was demonstrated with nisin where several variants of 8000 mutants had enhanced antimicrobial activity against resistant strains of bacteria (Field, 2008). Although nisin is used as an antimicrobial during food production and not necessarily as a therapy, the engineering tools utilized to optimize both production and enhanced functions can be leveraged to all therapeutic peptides. There will be great benefits in continuing to develop methods for industrial scale production of peptides and to expand their use as therapeutic agents. Nisin is a lantibiotic, derived by the ribosome expressed by bacteria, and has been engineered with improved efficacy (Field, 2008). Most of antimicrobial peptides that have been in clinical studies have not shown enhanced activity against bacteria resistant to multiple antibiotics in vivo (Vaara, 2009). These processes must constantly be optimized not only for improved recovery but also to ensure the efficacy is still meeting the demands.

It is important to note that often the peptide's therapeutic activity requires the mature peptide sequence. The gene encoding the peptide will not provide the full effect and the sequence of the peptide after modifications are made by the cell is the sequence that 
should be used (Maxwell, 2003). Should protein engineering be a strategy, it must not interfere with their efficacy in the case of cationic peptides. This means the net cationic charge and the amphiphilic structure which will decrease and change the activity of the peptide. More in vivo studies are needed to fully understand the stability of therapeutic peptides under meaningful physiological conditions when engineering peptide, proteins or pathways.

The feasibility has been demonstrated but supplying the demand for therapeutic peptides may still be years away before it is economically feasible. The best way to overcome the economics is to engineer bacterial strains to handle higher protein production and to make the cells more express proteins under a wider range of conditions by fine tuning their metabolic pathways. Screening workflows and advances in DNA sequencing are tools that will help develop these efforts and bring us closer to understanding how to better predict gene expression. This was shown after synthesizing thousands of combinations of regulatory elements, promoters and ribosomal binding sites, involved in controlling transcription and translation. These genes were inserted into $E$. coli to follow how these sequence combinations affect gene expression. This information may be important when building new strains to make novel products. Even though the growth rates were not studied in this experiment, it is a more holistic approach and can be extended to more organisms and more combinations of genes (Kosuri, 2013). Growth rates often suffer when altering their gene function but can be optimized. Viability of bacteria requires a balance of high fidelity replication while generating genetic diversity to enable adaptation to new and stressful environments and DNA repair mechanism have 
been optimized for engineering strains to better handle stress (Nyerges, 2014). The high expression of genes must not hinder cellular growth and optimizing growth rates should not alter gene expression. Finally, proper transport of proteins, whether it is a protein you are trying to express or a protein involved in healthy cell growth, will also need to be optimized. Stress proteins and the proteins that transport them are being modeled for their ability to enhance proper movement and folding of desired proteins (Dixit, 2012). These other proteins will play a role in overcoming the demands of industrial scale production.

An area of potential is with anti-venom therapies. Venom contains neurotoxic or hemotoxic proteins and sometimes both. The opossum, Didelphimorphia, is a large order of marsupials found in the western hemisphere that are resistant to most venoms and have the ability to tolerate a diet containing poisonous snakes. Lethal Toxin Neutralizing Factor (LTNF), a metalloproteinase inhibitor, was identified from opossum serum that enables the opossum to tolerate snake bites that often kill humans and dogs. The Lipps lab showed potential as use for anti-venom therapy by preventing death in mice that had otherwise perished in the control group. It was later shown that this protein could be fractionated into small peptide fragments that also have the same efficacy as the full LTNF protein (Lipps, 2000). In Table 2, the results from the Lipps study are shown. Five bio-toxins were tested on three test groups. The first group was given PBS as a control and all the mice died from all five toxins. In the second group, the synthetic peptide was administered two hours before the mice were given the toxins and all mice survived the toxin exposure administered. The third group was given the peptide two hours after being given lethal doses of the toxins and all those mice survived. Therefore, this data shows 
that the peptide is successful at reversing the effects of the bio-toxins up to two hours before the toxin exposure and up to two hours after exposure to the toxin.

Table 2: Summary of survival results in mice exposed to toxins.

\begin{tabular}{lccc}
\hline \multicolumn{1}{c}{ Toxin } & \multicolumn{3}{c}{ Mouse Survival/Death } \\
\cline { 2 - 4 } & $\begin{array}{c}\text { Control Group } \\
\text { (PBS) }\end{array}$ & $\begin{array}{c}\text { LT10 Group } \\
\text { 2 hours before } \\
\text { injection }\end{array}$ & $\begin{array}{c}\text { LT10 Group } \\
\text { hours after } \\
\text { injection }\end{array}$ \\
Western rattlesnake & $0 / 3$ & $3 / 0$ & $3 / 0$ \\
venom & & & $3 / 0$ \\
Cobratoxin & $0 / 3$ & $3 / 0$ & $3 / 0$ \\
Scorpion venom & $0 / 3$ & $3 / 0$ & $3 / 0$ \\
Honeybee venom & $0 / 3$ & $3 / 0$ & $3 / 0$ \\
Ricin & $0 / 3$ & $3 / 0$ & $3 / 0$ \\
Botulinum toxin & $0 / 3$ & $3 / 0$ & \\
\hline
\end{tabular}

Snake bites are a leading cause of death in India and Brazil and a lower cost therapy could save many lives especially in the most rural locations within these countries. In these developing countries, where snake bites are most prevalent, a biobased anti-venom therapy could eventually be a lower cost alternative to serum based therapies. The current method of treatment is to use horse serum. A horse is injected with the venom and produces antibodies against the venom. The horse is then bled for its serum, which is used to treat humans. This type of therapy can lead to other health issues for humans by inducing allergic responses to other proteins contained in the horse serum. In addition, this type of therapy is not low cost. Using opossum serum would also incur high costs because maintaining these animals safely would require large specialized facilities. Purification of the protein may decrease allergenicity but adds significant cost to an already costly production. 
The anti-venom peptide's role in the innate immune response could be another strategy to fight infection. Rather than directly acting on the venom, these peptides could serve the role as an immune modulator activating the immune response upon infection or aiding a small molecule or another protein by forming large pores in the cell membrane. Further studies of the structure function relationship will improve understanding of the therapeutic mechanisms in humans which is weak unless administered topically. With the large diversity of peptides, using more tissue specific peptides might improve overall specificity.

The Lipps lab showed a synthetic peptide could save the lives of mice when given variety of bio-toxins but a bio-based system for making an anti-venom therapy is in an early phase of developing an economical anti-venom therapy.

\section{Materials and Methods}

\section{Plasmid Prep}

The synthesized sequence of the desired anti-venom peptide was constructed onto a plasmid by Operon Labs in Mountain View, California. The gene was inserted into the $E$. coli expression plasmid pET29a (Figure 1a). The goal was to construct two plasmids containing snk1 and snk25 genes (Figure 1b). Snk1 is the single peptide sequence and the snk25 is a polypeptide sequence in which the peptide sequence repeated 25 times on the same plasmid. Once the plasmid contained snk genes, they were inserted into an expression strain, BL21. 


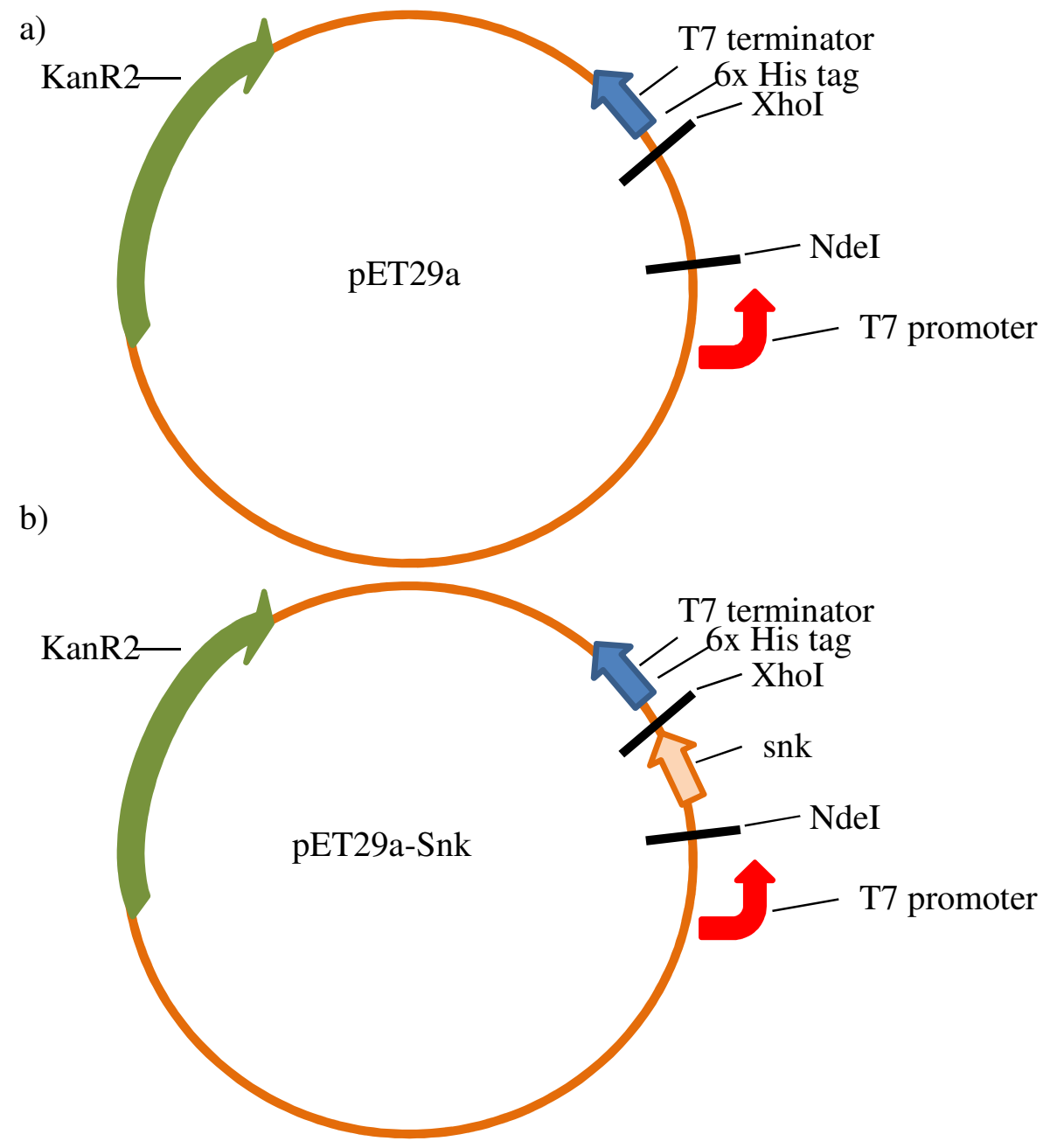

Figure 1. Cloning LTNF synthetic genes onto expression vector with novablue cells and euorfin plasmid. a) The pET29a plasmid b) Expression vector after cloning snk1 or snk23

The initial transformations with the plasmid DNA was performed using a heat shock protocol. $100 \mu \mathrm{L}$ of Novablue cells were transformed with $2 \mu 1$ of plasmid DNA ( 50 ng). This mixture was incubated at $41^{\circ} \mathrm{C}$ for 40 seconds before re-suspending in $250 \mu 1$ SOC medium. The cells were then spread across LB plates with $50 \mu \mathrm{g} / \mathrm{g}$ kanamycin. The plates were incubated overnight at $35^{\circ} \mathrm{C}$. Colonies that grew should contain the plasmid. To obtain plasmid DNA, a Life Technologies midi prep kit was used. 
There were two restriction sites used for cloning. Figure 2a shows optimized insert containing the snk1. Figure $2 b$ illustrates the insert for the snk25 gene.

a)

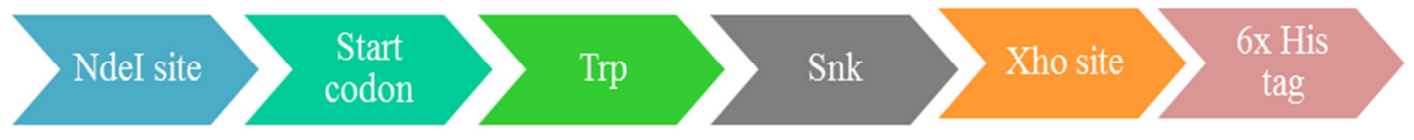

b)
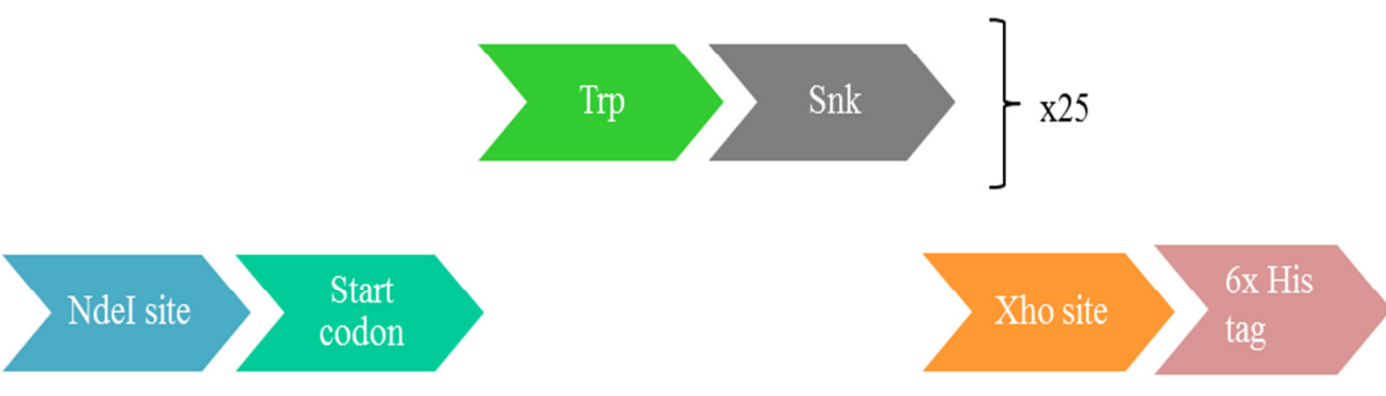

Figure 2. Insert optimized for expression of LTNF10 peptide. a) the single peptide insert b) the polypeptide insert

\section{Cloning and Sub-Cloning}

Plasmid DNA was collected using a Life Technologies midi prep kit as described in Life Technologies midi prep kit. The plasmids were cut at the Ndel and Xho sites. Two transformed cell cultures were used from the midipreps: one with pET plasmid and the other with Eurofin plasmid containing genes for peptides of interest, either snk1 or snk25. Agarose gel electrophoresis was used to purify the genes of interest and the cut pET plasmid for cloning. The circular DNA and cut fragments were run on $1 \%$ agarose gel 
containing ethidium bromide at a final concentration of $0.5 \mu 1 / \mathrm{ml}$ with TAE as the running buffer.

After extracting the gene of interest and the cut pET plasmid from the gel using the QIAquick Gel Extraction Kit from Qiagen, the DNA extracted from the gel was used for ligation and generation of the new pET plasmid containing the snk genes. The next step was to perform ligation of the snk genes into the cut pET plasmid using the Promega LigaFast Rapid DNA ligation system. The plasmid (Figure 1b) was transformed into Novablue cells using the transformation protocol described above. The cells containing the new plasmid could grow on LB media containing Kanamycin. The new strain was confirmed to contain the new insert after digestion and agarose gel confirmation described previously.

Next, the snk1 and snk25 plasmids were transformed into an E. coli strain that is optimized for expression, B121. This was achieved using same transformation and confirmation protocol described above. The first step was to obtain the plasmid DNA from the Novablue cells. Then, the plasmid DNA containing snk genes were transformed into B121 cells. Finally, the presence of plasmid DNA and the snk genes were confirmed using agarose gel electrophoresis.

\section{Expression and Recovery of Peptide}

$100 \mathrm{~mL}$ shake flasks and $2 \mathrm{~L}$ bio-reactors were used for protein expression. One $\mathrm{mM}$ IPTG was used to induce protein production. It was expected that the peptides would be in the cell lysate. After growing the cells in a shake flask or in the bio-reactor, the medium was centrifuged in a Thermos Scientific Heraeus table top centrifuge at $300 \mathrm{~g}$, 
resulting in a wet cell pellet. The supernatant was stored cold. Sodium dodecyl sulfate polyacrylamide gel electrophoresis, SDS PAGE, in combination with Coomassie staining were used to visualize the peptides. In procedure used, $0.05 \mathrm{ml}$ of processed broth sample was added to $0.05 \mathrm{ml}$ of hydrochloric acid and mixed well. Then $0.05 \mathrm{ml}$ of sodium dodecyl sulfate (SDS) was added and the solution was mixed. This sample was incubated $5 \mathrm{~min}$ on ice before spinning out solids for $2 \mathrm{~min}$ at 14,000 rpm using Eppendorf $5430 \mathrm{R}$ microfuge. $0.02 \mathrm{ml}$ of the supernatant was added to 4-12\% Bis-Tris, 10 or 12 well, polyacrylamide gel and run for up to $45 \mathrm{~min}$ at $120 \mathrm{mV}$. After separation by SDS PAGE, the gel was stained with Coomassie for 5 minutes. After staining, the stained gel was rinsed 3 times with deionized (DI) water, then submerged in $10 \%$ methanol with $10 \%$ acetic acid to de-stain overnight. The de-stained gel was again rinsed with DI water 3 times before scanning or photographing. The SDS PAGE gels used were pre-casted from Novex. Bis-Tris gels (4-12\%), $1 \mathrm{~mm}$ thick with 10 or 12 wells.

Downstream from the (poly)peptide sequence, there is a $6 \mathrm{x}$ his tag before the termination sequence. The protocol for the his-stain was obtained from the 6x his stain kit produced by Peirce Scientific.

First, homogenization was utilized to break up the cells but there was difficulty in separating out the cell debris from the lysate due to the high viscosity of the sample, so the cells were lysed using Bugbuster Protein Extraction reagent from Novagen. $2.5 \mathrm{ml}$ of Bugbuster reagent was mixed with a pellet made from $50 \mathrm{ml}$ of cell culture. To this mixture, $0.1 \mathrm{mg}$ of lysozyme was added. This supernatant was also collected after centrifugation and run on SDS PAGE. The pellet was further treated with $8 \mathrm{M}$ urea 
solution in water. For each pellet generated from $50 \mathrm{ml}$ of culture, $1 \mathrm{ml}$ of $8 \mathrm{M}$ urea was added and then the pellets incubated overnight with urea. From this urea treated pellet, the band of the snk23 was seen on the SDS PAGE gel after Coomassie staining.

Downstream from the (poly)peptide sequence, there is a $6 \mathrm{x}$ his tag before the termination sequence. This was used to confirm that the peptide of interest was being produced using a $6 \mathrm{x}$ his stain kit produced by Peirce Scientific. The protocol for the hisstain was obtained from the manufacturer.

\section{Results}

\section{Plasmid Construction}

The snk1 and snk25 plasmids were transformed into Novablue cells using a standard heat shock protocol. The cells were plated onto LB plates with kanamycin to select for the transformed species. An isolated colony was used to confirm the presence of the peptide after midiprep. After digestion with restriction enzymes, the plasmid DNA was separated using agarose gel separation (Figure 3).

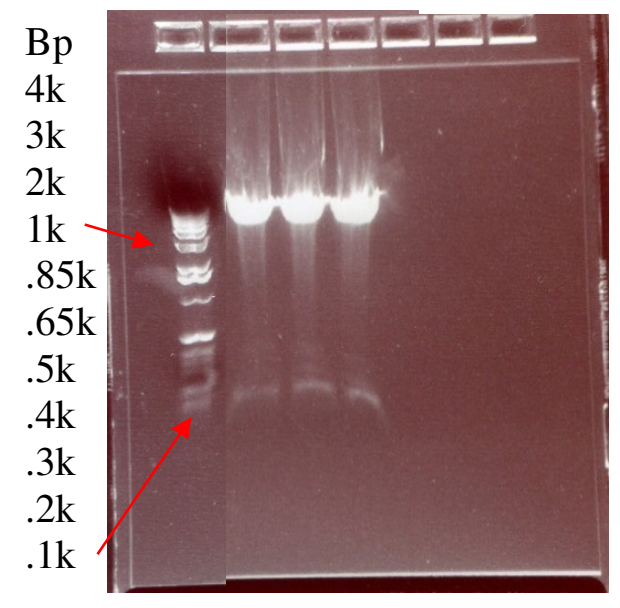

Figure 3. DNA gel verifying the presence of the plasmid containing snk1 insert. Lane 1 contains the molecular marker. Lanes 2-5 contain the plasmid DNA after restriction 
digest. The larger band is the plasmid DNA and the smaller band is the snk1 gene cut out of the plasmid.

The snk1 and snk23 containing inserts were cut out and extracted for ligation along with the cut pET plasmid. The new plasmids were transformed into Novablue cells and the presence of the plasmid was confirmed using agarose gel electrophoresis. The new plasmid was then inserted into a cell line that is used for expression, B121.

\section{Expression and Downstream Processing}

The larger polypeptide, snk25, was shown to express in shake flasks but it was not in the soluble portion of the cell lysate. The expectation was to find the peptide in the supernatant of the fermentation broth after cell lysis. Figure 4 shows the banding pattern after the cell lysis with and without the inducer but the results were inconclusive. 


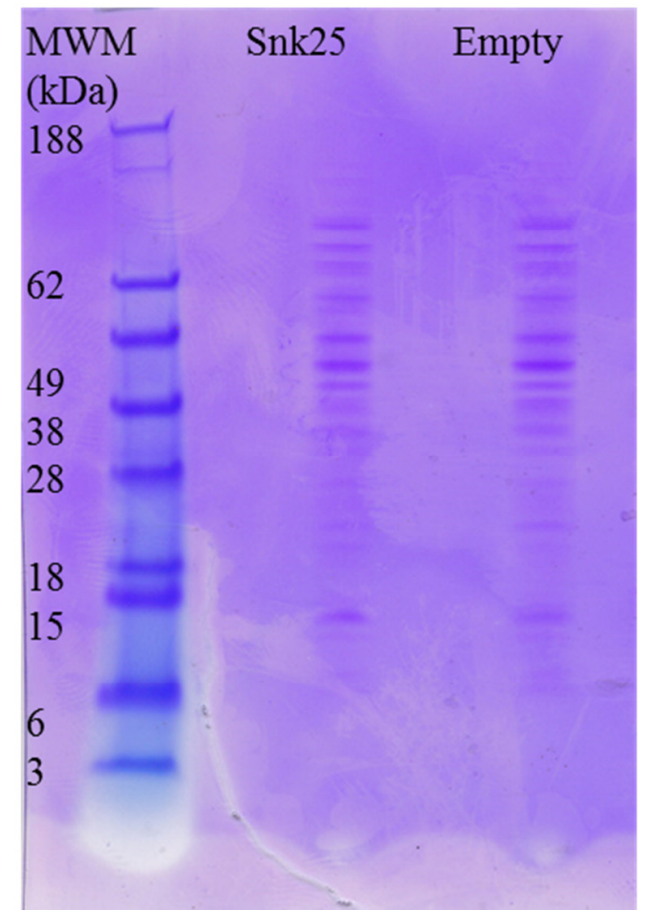

Figure 4. SDS PAGE gel showing protein expression in the cell lysate. Lane 1 is the MWM. Lane 3 the protein expressed in the cells containing the snk plasmid. Lane 5 shows the protein expression in the cells containing the plasmid without the snk gene inserted. There were no differences observed.

It was eventually found in an inclusion body preparation. This became evident in an experiment in which the cell pellet containing the inclusion bodies was solubilized with $8 \mathrm{M}$ urea and then run on SDS PAGE to look for the polypeptide in the insoluble portion of the lysed broth. A follow up experiment was run in shake flasks to confirm this result. The samples were compared with and without the addition of an inducer. Both the soluble fraction and the insoluble fraction were processed for SDS PAGE analysis. Figure 5 shows the results of SDS PAGE gel. A band of the expected size, $\sim 30 \mathrm{kDa}$, was seen in the samples after induction and in the insoluble (inclusion body) fraction. In addition, to see the expression over time, time points were taken and the band of expected size was seen in all time points after induction. 


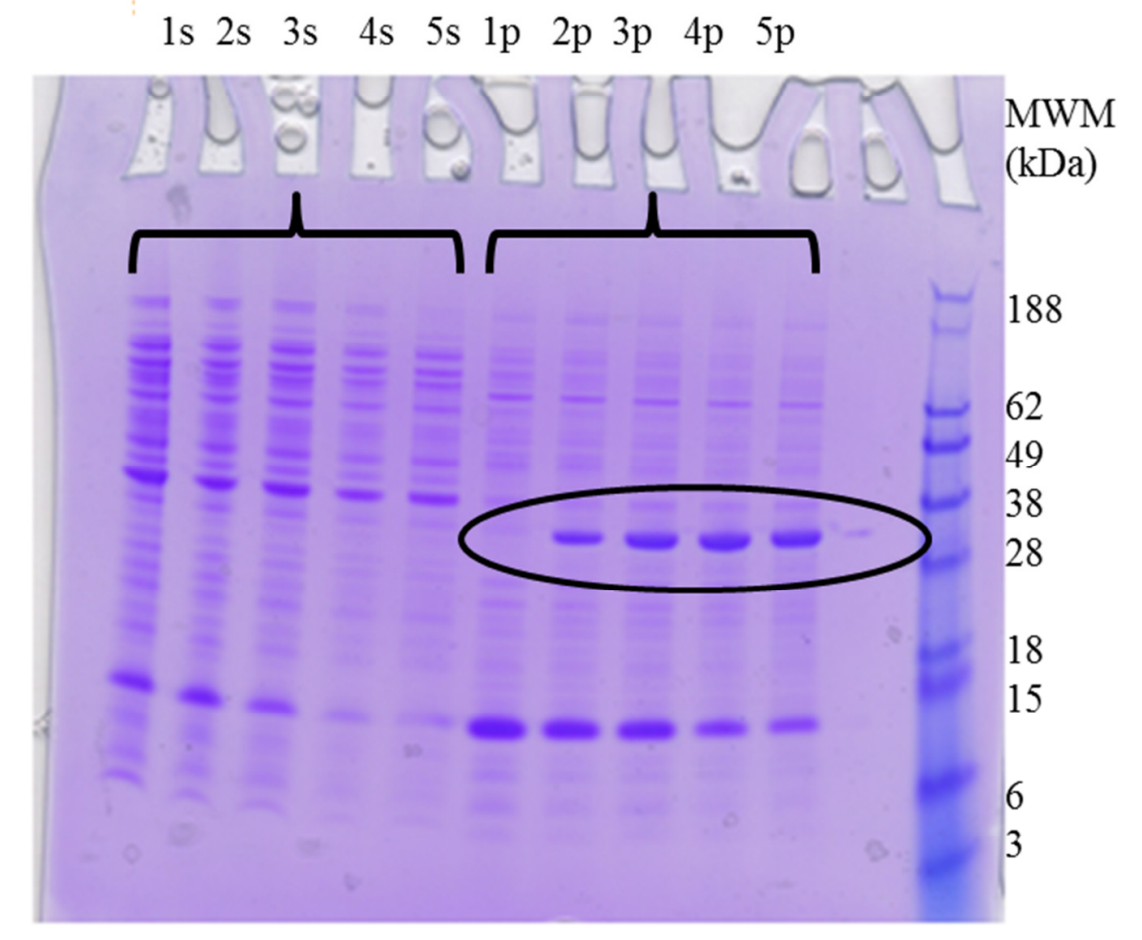

Figure 5. SDS PAGE gel showing snk25 expression time course during shake flask experiment. Lane 1-5 are supernatants after lysis of the cells taken at increasing timepoints, approximately every 5-6 hours. No band of interest is present. Lane 6-10 are the supernatants after treating the cell pellet with $8 \mathrm{M}$ urea at the same time-points are in lane 1-5. Lane 7-10 are after induction and the band of expected size is seen.

After the positive results from the shake flask experiments, a $2 \mathrm{~L}$ fermentation was run with the new plasmid containing strains. From the insoluble fraction, the results were again positive and the same bands at the expected size were stained only after induction. Figure 6 shows the SDS-PAGE gel after a 2 L fermentation. 


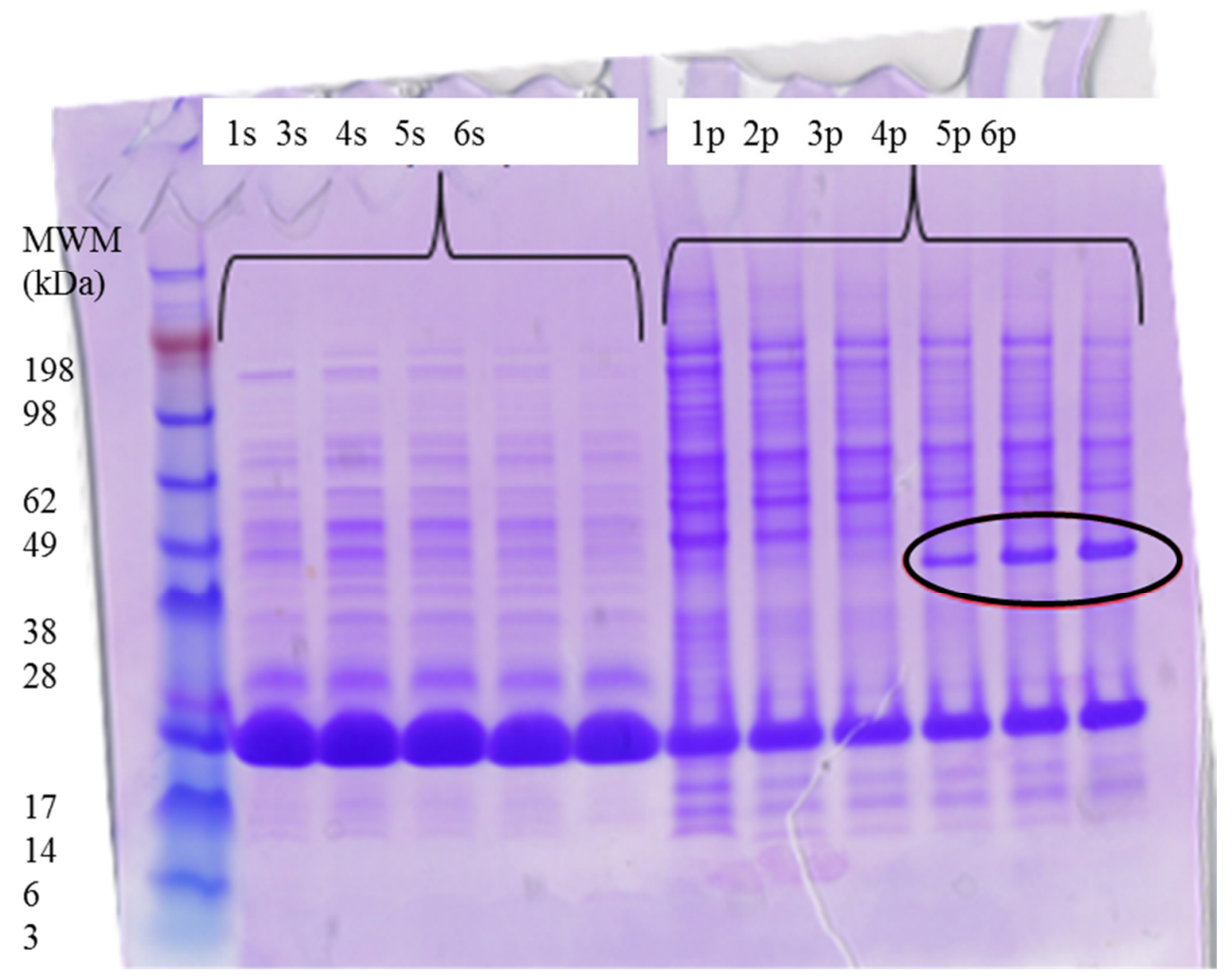

Figure 6. SDS PAGE gel from snk 25 fermentation samples: Lane 1 is the marker. Lane 2-6 contains samples taken at increasing time-points during the fermentation after lysis of the cells and harvesting the supernatant. No band of interest is present. In lanes 7-12 are also samples taken at increasing time-points during the fermentation after treating the lysed cell pellet with 8M urea. Lane 10-12 are after induction with 1mM IPTG and the snk25 band is now present.

To confirm that this band is in fact our snk25 poly-peptide, an SDS PAGE gel was stained with a $6 x$ his-stain. This stain confirmed the results of the Coomassie-stained gel and provided more confirmation that this polypeptide is his-tagged and likely snk25. Figure 7 shows the his-stained gel from the shake flasks which correspond to the Coomassie-stained gel shown in Figure 5. 


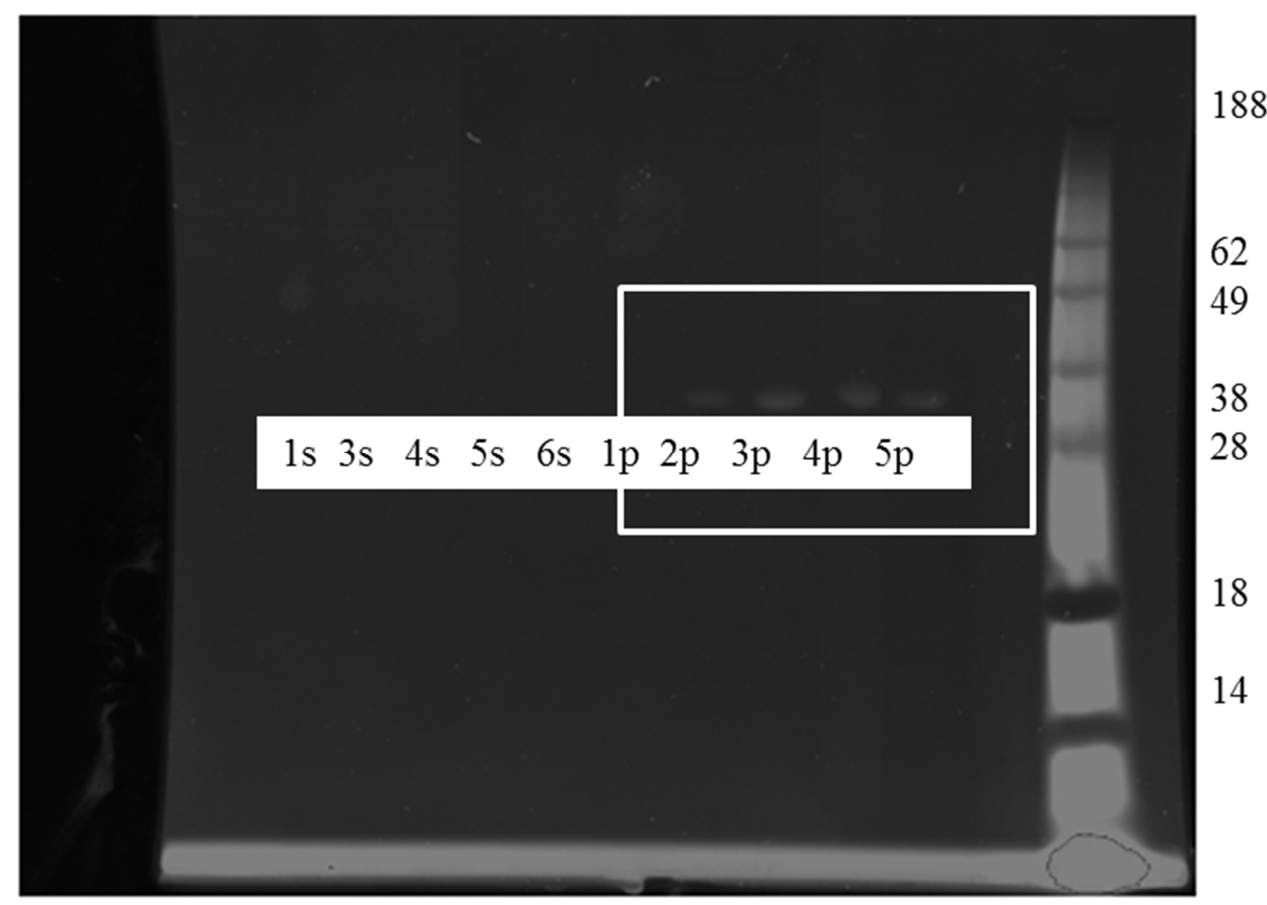

Figure 7. His-stained gel. Lane 1-5 are supernatants after lysis of the cells taken at increasing time-points. No band of interest is present. Lane 6-10 are the supernatants after treating the cell pellet with $8 \mathrm{M}$ urea at the same time-points are in lane 1-5. Lanes 25 and 7-10 are after induction. The band of expected size is seen after induction and only in the insoluble portion of the cell lysate.

To confirm that the polypeptide with the his-tag can also be produced in the $2 \mathrm{~L}$ bioreactor, an SDS-PAGE gel corresponding to figure 6 was run and then stained with the his-stain. Figure 8 shows a band of expected size illuminate though it is not as intense as the shake flask experiments, possibly because degradation is already occurring. 


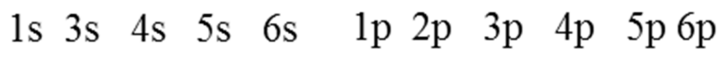

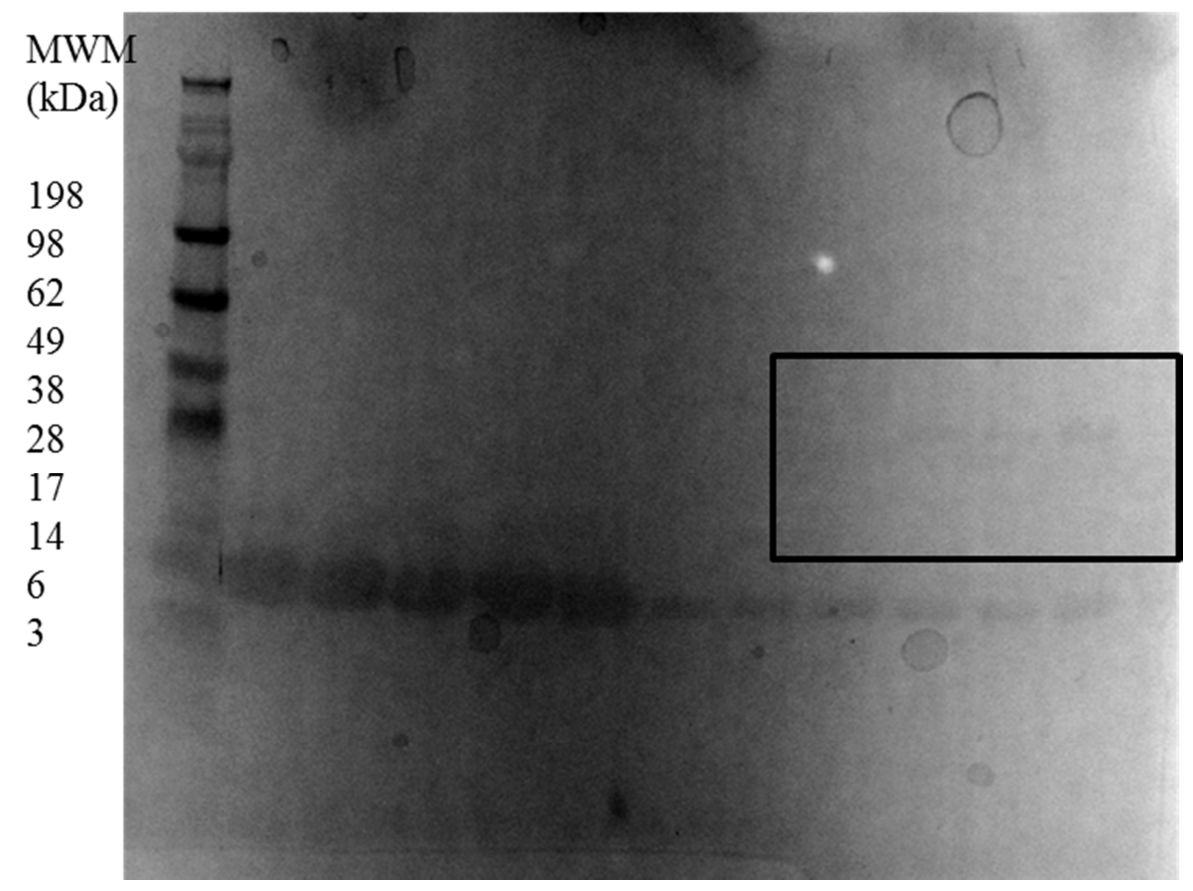

Figure 8. His-stained gel from fermentation of snk25. Lane 2-6 are samples taken at increasing time-points during the fermentation after lysis of the cells and harvesting the supernatant. No band of interest is present. In lanes 7-12 are also samples taken at increasing time-points during the fermentation after treating the lysed cell pellet with $8 \mathrm{M}$ urea. Lane 10-12 are after induction with 1mM IPTG and the snk25 band is now present.

The shake flask experiments and the 2 L bioreactor experiments with snk1 were not conclusive. For the snk1 peptide, the SDS PAGE method described above was unsuccessful, so a different gel was tried. $10-20 \%$ tricine gels from Invitrogen can resolve lower molecular weight species but still was not able to resolve the small peptide.

The expression of snk25 was confirmed using His stain from Pierce scientific kit after SDS PAGE to separate the proteins. While snk25 illuminated in the $6 \mathrm{x}$ stain, the snk1 staining was unsuccessful thus far and consistent with SDS PAGE observations. 
It was not illuminated on SDS PAGE gel with neither Coomassie nor with the $6 \mathrm{x}$ hisstain kit. The ability to visualize such a small peptide using SDS-PAGE is very limited. Several systems and samples preps were tried to see the snk1 band which is described in the Discussion section.

\section{Discussion}

Opossum's serum has been shown to provide lifesaving benefits in mice that were given a variety of venoms and other biological toxins including ricin and botulinum (Lipps, 1999; Lipps, 2000). A small peptide sequence fractionated from LTNF was shown to prevent death caused by snake venom in mice and was successfully expressed in $E$. coli. Snk25 may have been more stable in the cell because it was packaged in an inclusion body whereas snk1 may not have been. Still, the downstream recovery and application performance will need to be demonstrated. Even though inclusion bodies are not preferred, it can be beneficial to have a peptide or protein of interest in an inclusion body rather than freely transported around the cell (Ramón, 2014). The inclusion body can protect from proteolysis and may even prevent aggregation when high levels of protein expression are reached within the cell. It may just require another method of visualization to see snk1. Several attempts were made to visualize snk1 including running the gel for half the time in case the small $1.1 \mathrm{kDa}$ peptide is running off the gel. In addition, concentration and separation techniques were implemented for both shake flasks and $2 \mathrm{~L}$ bioreactor samples. The samples which were present in the cell lysate and the cell pellet after treatment were included and exposed to many conditions to visualize this small species. The supernatant after spinning cells down for 5 min at $14 \mathrm{k}$ were 
analyzed by SDS PAGE to see if the peptide might be secreted and found in the (previously discarded) supernatant. The insoluble portions were treated with Bug Buster, urea, and lysozyme but the band of expected size was not observed. The washes were also analyzed but the snk1 band was not visible with SDS PAGE or his-staining. Components larger than $5 \mathrm{kDa}$ were separated out so only species smaller than $5 \mathrm{kDa}$ are present. The desired peptide still was not observed, so the sample was concentrated $2 \mathrm{x}$ using a Savant ${ }^{\mathrm{TM}}$ Explorer SpeedVac ${ }^{\mathrm{TM}}$. Finally, purification thru nickel affinity column was performed using HisPurTM Ni-NTA Resin and concentrated in Savant ${ }^{\mathrm{TM}}$ Explorer SpeedVac ${ }^{\mathrm{TM}}$, but still no band was observed.

The presence of mRNA in the cell should be confirmed, which would be evidence that the snk1 peptide is being expressed. With mRNA experiments, it will become evident what the level of expression is for the peptide. If the level is low, more copies may be placed on the plasmid or the cell's transcriptional machinery needs to be over activated. Sometimes, a different promoter is needed for the expression levels to be high enough to confirm their presence.

It is very likely that the expression system is working and may have even recovered the snk1 peptide from the cells, but the visualization method is wrong for such a small species. The Coomassie stain used is very good for visualizing proteins because it binds to the protein's positive charge but with such a small peptide which may be expressed at low levels, there may not be a large enough peptide to dye ratio to see the peptide. If the peptide is being degraded before visualization, but is being recovered from the cells, it could indicate the peptide is very unstable, especially if mRNA results 
show expression. Small peptides may still be targets for proteolysis but the sample was spun through a 5 MWCO centricon to remove proteases or other enzymes that may degrade the peptide. If the peptide was aggregating, then it may have been filtered out. Also, it could aggregate during the sample prep of the SDS PAGE and the aggregate migrated appropriately but unexpectedly.

Other molecular biology techniques may help confirm the snk1 expression and aid the recovery. Perhaps a GFP tag or some other fluorescent, active tag can be used and visualized by flow cytometry. Another approach could be to add a linker protein to the peptide which can help with expression or even make the molecule bigger and easier to visualize on SDS PAGE.

It is also possible that the cell is not making this peptide and the cells need further manipulation. To influence cells to produce a protein, the right balance of other proteins and compounds must be maintained within the cell. Additional modifications may be required to keep this balance. Gyrase activation requires ATP which requires ATP synthase. By not providing the right balance of these two enzymes, the cell may go into the stationary phase rather than being maintained in the growth phase (Gutiérrez-Estrada, 2014). When engineering cells to overexpress proteins, understanding the entire pathway and all the proteins involved, and maintaining balance in the cell will increase fitness during stressful times and lead to better performing compounds. To identify new genes that are associated with the global regulatory circuit, the Gac lab tracked populations for 1000 generations under four different environmental conditions (Gac, 2013). Starting with a common ancestor, the carbon food source varied in four different conditions and 
evolved clones from these conditions were sampled at different time points, assayed and further tested after growth in all four conditions. All populations could adapt to their environment and they found specific genes that were modified across all environments, although the patterns of the modifications varied across the different conditions. The genes identified were generally associated with catabolism, as expected, based on carbon being the varied condition. The Gac lab concluded that populations sharing historical pressures react more similarly in a changing environment compared with populations that have similar gene mutations under different conditions. The cells that came from the same condition had similar activity when they were subjected to new carbon sources, while cells from the different carbon environments, where similar gene mutations were identified, behaved differently after they were placed in similar carbon sources (Gac, 2013). This indicates that adaptation mutations may be related to improvements in catabolic pathways. At the nucleotide level, the process of translation is generally conserved but the mechanism behind how the translational apparatus adapts to changing environments is not fully understood. The tRNA pool will rapidly change and evolve to meet translational demands and to maintain proper cell balance. Through mutations in the tRNA pool, cells do have the ability to rapidly change the tRNAs under different conditions because they are part of a multimember gene family. Eventually, throughout a longer timescale, the genome will change and evolve (Yona, 2013). Based on this observation, it is possible the cell is not transcribing snk1.

The fermentation and recovery processes have not been fully optimized. Changes to the medium or fermentation conditions may also help increase the peptide production to a 
level that can be seen by SDS PAGE. Media improvements are product dependent. Reducing the amount of phosphate, adjusting the $\mathrm{pH}$ slightly or increasing the number of certain vitamins may enhance the level of product being made by each cell. Optimizing the number of peptide repeats in the polypeptide sequence may also be beneficial. This can impact the processing within the cell and determine if it is secreted, excreted or degraded.

\section{Conclusion}

Optimizing the production of snk1 and snk25 will provide a low-cost alternative to treat snake bites compared to the traditional horse serum based treatment. The first step is to utilize biotechnology system to produce a low cost anti-venom. The construction of two strains containing an antivenom peptide was successful. The SDS PAGE gel showed evidence of snk25 expression. For snk1, the expression was challenging to confirm but agarose gel electrophoresis and sequencing (sequencing done by Quintara Biosciences, data not included) showed that the snk1 DNA is present. 


\section{References}

Arnold, C. (2016). Vipers, mambas and taipans: the escalating health crisis over snakebites. Nature, 537, 26-28.

Bokinsky, G., Peralta-Yahya, P. P., George, A., Holmes, B. M., Steen, E. J., Dietrich, J., ... \& Keasling, J. D. (2011). Synthesis of three advanced biofuels from ionic liquid-pretreated switchgrass using engineered Escherichia coli. Proceedings of the National Academy of Sciences, 108, 19949-19954.

Bowdish, D. M., Davidson, D. J., Scott, M. G., \& Hancock, R. E. (2005). Immunomodulatory activities of small host defense peptides. Antimicrobial agents and chemotherapy, 49(5), 1727-1732.

Bush, K., Macielag, M. \& Weidner-Wells, M. Taking inventory: antibacterial agents currently at or beyond Phase 1. Curr. Opin. Microbiol. 7, 466-476 (2004).

Catanzariti, A. M., Soboleva, T. A., Jans, D. A., Board, P. G., \& Baker, R. T. (2004). An efficient system for high-level expression and easy purification of authentic recombinant proteins. Protein Science, 13, 1331-1339.

Chabeaud, A., Vandanjon, L., Bourseau, P., Jaouen, P., Chaplain-Derouiniot, M., \& Guérard, F. (2009). Performances of ultrafiltration membranes for fractionating a fish protein hydrolysate: application to the refining of bioactive peptidic fractions. Separation and Purification Technology, 66, 463-471.

Corzett, C. H., Goodman, M. F., \& Finkel, S. E. (2013). Competitive fitness during feast and famine: how SOS DNA polymerases influence physiology and evolution in Escherichia coli. Genetics, 194, 409-420.

Dahl, J. U., Koldewey, P., Salmon, L., Horowitz, S., Bardwell, J. C., \& Jakob, U. (2015). HdeB functions as an acid-protective chaperone in bacteria. Journal of Biological Chemistry, 290, 65-75.

Dixit, A., \& Verkhivker, G. M. (2012). Probing molecular mechanisms of the Hsp90 chaperone: Biophysical modeling identifies key regulators of functional dynamics. PLoS One, 7, e37605.

Field, D., Connor, P. M., Cotter, P. D., Hill, C., \& Ross, R. P. (2008). The generation of nisin variants with enhanced activity against specific gram-positive pathogens. Molecular Microbiology, 69, 218-230.

Fogarty, W. M., \& Kelly, C. T. (Eds.). (2012). Microbial Enzymes and Biotechnology. Springer Science \& Business Media. 
Glenn, A. R. (1976). Production of extracellular proteins by bacteria. Annual Reviews in Microbiology, 30, 41-62.

Gac, M., Cooper, T. F., Cruveiller, S., Médigue, C., \& Schneider, D. (2013). Evolutionary history and genetic parallelism affect correlated responses to evolution. Molecular Ecology, 22(, 3292-3303.

Gutiérrez-Estrada, A., Ramírez-Santos, J., \& del Carmen Gómez-Eichelmann, M. (2014). Role of chaperones and ATP synthase in DNA gyrase reactivation in Escherichia coli stationary-phase cells after nutrient addition. SpringerPlus, 3, 1.

Hajji, M., Jellouli, K., Hmidet, N., Balti, R., Sellami-Kamoun, A., \& Nasri, M. (2010). A highly thermostable antimicrobial peptide from Aspergillus clavatus ES1: biochemical and molecular characterization. Journal of Industrial Microbiology \& Biotechnology, 37, 805-813.

Hancock, R. E., \& Lehrer, R. (1998). Cationic peptides: a new source of antibiotics. Trends in Biotechnology, 16, 82-88.

Hancock, R. E., \& Rozek, A. (2002). Role of membranes in the activities of antimicrobial cationic peptides. FEMS Microbiology Letters, 206, 143-149.

Hancock, R. E., \& Sahl, H. G. (2006). Antimicrobial and host-defense peptides as new anti-infective therapeutic strategies. Nature Biotechnology, 24, 1551-1557.

Hartmann, R., \& Meisel, H. (2007). Food-derived peptides with biological activity: from research to food applications. Current Opinion in Biotechnology, 18, 163-169.

Hong, W., Wu, Y. E., Fu, X., \& Chang, Z. (2012). Chaperone-dependent mechanisms for acid resistance in enteric bacteria. Trends in Microbiology, 20, 328-335.

Huffer, S., Roche, C. M., Blanch, H. W., \& Clark, D. S. (2012). Escherichia coli for biofuel production: bridging the gap from promise to practice. Trends in Biotechnology, 30, 538-545.

Jansa, S. A., \& Voss, R. S. (2011). Adaptive evolution of the venom-targeted vWF protein in opossums that eat pitvipers. PLoS One, 6, e20997.

Kasturiratne, Anuradhani, et al. "The global burden of snakebite: a literature analysis and modelling based on regional estimates of envenoming and deaths." PLoS Med 5.11 (2008): e218. 
Krause WJ, Krause WA: The Opossum: Its Amazing Story. 2006, University of Missouri, Columbia, Department of Pathology and Anatomical Sciences, retrieved from https://mospace.umsystem.edu/xmlui/bitstream/handle/10355/15130/OpossumItsAma zingStory.pdf?sequence $=1$ \&isAllowed=y.

Kitts, D. D., \& Weiler, K. (2003). Bioactive proteins and peptides from food sources. Applications of bioprocesses used in isolation and recovery. Current Pharmaceutical Design, 9, 1309-1323.

Kosuri, S., Goodman, D. B., Cambray, G., Mutalik, V. K., Gao, Y., Arkin, A. P., ... \& Church, G. M. (2013). Composability of regulatory sequences controlling transcription and translation in Escherichia coli. Proceedings of the National Academy of Sciences, 110, 14024-14029.

Lennen, R. M., Kruziki, M. A., Kumar, K., Zinkel, R. A., Burnum, K. E., Lipton, M. S., ... \& Pfleger, B. F. (2011). Membrane stresses induced by overproduction of free fatty acids in Escherichia coli. Applied and Environmental Microbiology, 77, 81148128.

Lennen, R. M., Politz, M. G., Kruziki, M. A., \& Pfleger, B. F. (2013). Identification of transport proteins involved in free fatty acid efflux in Escherichia coli. Journal of Bacteriology, 195, 135-144.

Li, B., Chen, F., Wang, X., Ji, B., \& Wu, Y. (2007). Isolation and identification of antioxidative peptides from porcine collagen hydrolysate by consecutive chromatography and electrospray ionization-mass spectrometry. Food Chemistry, 102, 1135-1143.

Lipps, B. V. (1999). Anti-lethal factor from opossum serum is a potent antidote for animal, plant and bacterial toxins. Journal of Venomous Animals and Toxins, 5, 56-66.

Lipps, B. V. (2000). Small synthetic peptides inhibit, in mice, the lethalithy of toxins derived from animal, plant and bacteria. Journal of Venomous Animals and Toxins, 6 , $77-86$

MacGilvray, M. E., Lapek Jr, J. D., Friedman, A. E., \& Quivey Jr, R. G. (2012). Cardiolipin biosynthesis in Streptococcus mutans is regulated in response to external pH. Microbiology, 158, 2133-2143.

Matteo, C. C., Cooney, C. L., \& Demain, A. L. (1976). Production of gramicidin S synthetases by Bacillus brevis in continuous culture. Microbiology, 96, 415-422.

Maxwell, A. I., Morrison, G. M., \& Dorin, J. R. (2003). Rapid sequence divergence in mammalian $\beta$-defensins by adaptive evolution. Molecular Immunology, 40, 413-421. 
Meisel, H., \& Schlimme, E. (1990). Milk proteins: precursors of bioactive peptides. Trends in Food Science \& Technology, 1, 41-43.

Miroux, B., \& Walker, J. E. (1996). Over-production of proteins inEscherichia coli: mutant hosts that allow synthesis of some membrane proteins and globular proteins at high levels. Journal of Molecular Biology, 260, 289-298.

Mogk, A., Deuerling, E., Vorderwülbecke, S., Vierling, E., \& Bukau, B. (2003). Small heat shock proteins, $\mathrm{ClpB}$ and the DnaK system form a functional triade in reversing protein aggregation. Molecular Microbiology, 50, 585-595.

Nyerges, Á., Csörgő, B., Nagy, I., Latinovics, D., Szamecz, B., Pósfai, G., \& Pál, C. (2014). Conditional DNA repair mutants enable highly precise genome engineering. Nucleic Acids Research, 42, e62-e62.

Perez, J. C., Pichyangkul, S., \& Garcia, V. E. (1979). The resistance of three species of warm-blooded animals to western diamondback rattlesnake (Crotalus atrox) venom. Toxicon, 17, 601-607.

Peschel, A., \& Sahl, H. G. (2006). The co-evolution of host cationic antimicrobial peptides and microbial resistance. Nature Reviews Microbiology, 4, 529-536.

Raman, S., Rogers, J. K., Taylor, N. D., \& Church, G. M. (2014). Evolution-guided optimization of biosynthetic pathways. Proceedings of the National Academy of Sciences, 111, 17803-17808.

Ramón, A., Señorale-Pose, M., \& Marín, M. (2014). Inclusion bodies: not that bad... Recombinant protein expression in microbial systems, 53.

Randall, C. P., Gupta, A., Jackson, N., Busse, D., \& O'Neill, A. J. (2015). Silver resistance in Gram-negative bacteria: a dissection of endogenous and exogenous mechanisms. Journal of Antimicrobial Chemotherapy, dku523.

Remijsen, Q., Verdonck, F., \& Willems, J. (2010). Parabutoporin, a cationic amphipathic peptide from scorpion venom: much more than an antibiotic. Toxicon, 55, 180-185.

Rossi, L. M., Rangasamy, P., Zhang, J., Qiu, X. Q., \& Wu, G. Y. (2008). Research advances in the development of peptide antibiotics. Journal of Pharmaceutical Sciences, 97, 1060-1070.

Rossi, D. C., Muñoz, J. E., Carvalho, D. D., Belmonte, R., Faintuch, B., Borelli, P., ... $\&$ Daffre, S. (2012). Therapeutic use of a cationic antimicrobial peptide from the spider Acanthoscurria gomesiana in the control of experimental candidiasis. BMC Microbiology, 12, 1. 
Sørensen, H. P., \& Mortensen, K. K. (2005). Advanced genetic strategies for recombinant protein expression in Escherichia coli. Journal of Biotechnology, 115, 113-128.

Tenaillon, O., Rodríguez-Verdugo, A., Gaut, R. L., McDonald, P., Bennett, A. F., Long, A. D., \& Gaut, B. S. (2012). The molecular diversity of adaptive convergence. Science, 335, 457-461.

Toke, O. (2005). Antimicrobial peptides: new candidates in the fight against bacterial infections. Peptide Science, 80, 717-735.

Tsai, M., Ohniwa, R. L., Kato, Y., Takeshita, S. L., Ohta, T., Saito, S., ... \& Morikawa, K. (2011). Staphylococcus aureus requires cardiolipin for survival under conditions of high salinity. BMC microbiology, 11,1 .

Vaara, M. (2009). New approaches in peptide antibiotics. Current Opinion in Pharmacology, 9, 571-576.

Wang, W., Rasmussen, T., Harding, A. J., Booth, N. A., Booth, I. R., \& Naismith, J. H. (2012). Salt bridges regulate both dimer formation and monomeric flexibility in HdeB and may have a role in periplasmic chaperone function. Journal of Molecular Biology, 415, 538-546.

White, D., Drummond, J. T., \& Fuqua, C. (1995). The physiology and biochemistry of prokaryotes (pp. 34-46). New York: Oxford University Press.

Witkin, E. M. (1976). Ultraviolet mutagenesis and inducible DNA repair in Escherichia coli. Bacteriological Reviews, 40, 869.

Wu, Z., Hoover, D. M., Yang, D., Boulègue, C., Santamaria, F., Oppenheim, J. J., ... $\& \mathrm{Lu}, \mathrm{W}$. (2003). Engineering disulfide bridges to dissect antimicrobial and chemotactic activities of human $\beta$-defensin 3. Proceedings of the National Academy of Sciences, 100, 8880-8885.

Yeaman, M. R., \& Yount, N. Y. (2003). Mechanisms of antimicrobial peptide action and resistance. Pharmacological Reviews, 55, 27-55.

Yim, H., Haselbeck, R., Niu, W., Pujol-Baxley, C., Burgard, A., Boldt, J., ... \& Estadilla, J. (2011). Metabolic engineering of Escherichia coli for direct production of 1, 4-butanediol. Nature Chemical Biology, 7, 445-452.

Yona, A. H., Bloom-Ackermann, Z., Frumkin, I., Hanson-Smith, V., CharpakAmikam, Y., Feng, Q., ... \& Pilpel, Y. (2013). tRNA genes rapidly change in evolution to meet novel translational demands. Elife, 2, e01339. 
Yoshikawa, M., Fujita, H., Matoba, N., Takenaka, Y., Yamamoto, T., Yamauchi, R., ... \& Takahata, K. (2000). Bioactive peptides derived from food proteins preventing lifestyle-related diseases. Biofactors, 12(1-4), 143-146.

Zhao, P., \& Cao, G. (2012). Production of bioactive sheep $\beta$-defensin-1 in Pichia pastoris. Journal of Industrial Microbiology \& Biotechnology, 39, 11-1 